\title{
Is religious fundamentalism our default spirituality?: Implications for teacher education
}

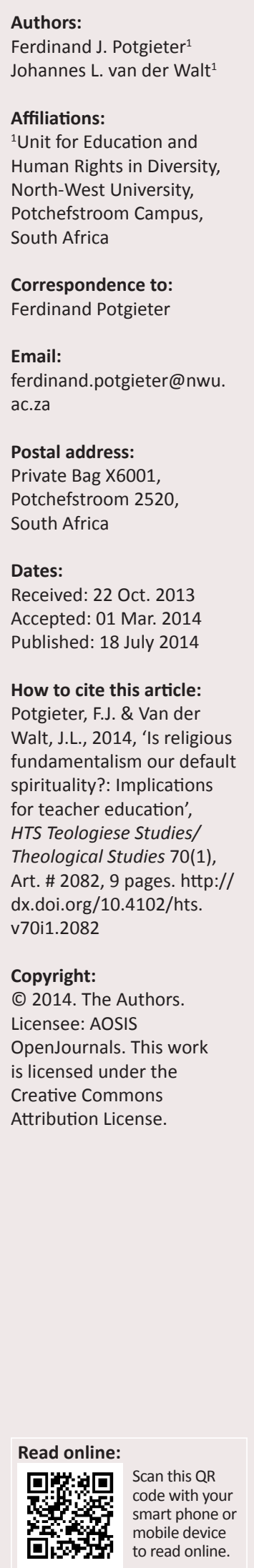

Using experiential interpretivism as underpinning methodology, this article investigates whether religious fundamentalism is the default spirituality of human beings. Our research is based on a hermeneutic reconstructive interpretation of religion, fundamentalism, radicalism, extremism, spirituality, life- and worldview, and the role of education in bringing about peaceful coexistence amongst people. We concluded that the natural religious-fundamentalist inclination of the human being tends to be (and needs to be) counterbalanced by the education - that is, socialisation - that he or she receives from the moment of birth, the important first six or seven years of life, and throughout his or her life. Based on this conclusion, the article ends with the articulation of ten implications for teacher education.

\section{Introduction}

As educationists, we often come across religious views that appear to be fundamentalist; in other words, the views of some of the adherents to a particular religion that seem to gravitate towards the most fundamental tenets of their religion or worldview, and hence cause them to fall into religious or other forms of extremism. Such people seem to overlook the need for their religious or worldview precepts to be couched in, and to be contextualised by, social conditions that will ideally change those precepts into a more balanced approach to what they regard as the transcendental force in their lives, to life in general, and to other people. According to Law (2011):

Faith, taken to an extreme [...] makes it difficult to communicate with people. One can no longer reason or argue with [such extremists]. If people with an extreme faith get it into their heads that they should do some terrible thing (perhaps kill those with religious beliefs different from their own), it may be impossible to make them see that what they are doing is wrong. They won't listen to reason. (p. 207)

Their attitude amounts to what J.S. Mill referred to as mental slavery, dogmatism and repression (Morton 1998:172-173). Wolmarans (2013) refers to it as:

$[A]$ way of thinking based upon selected holy texts, as well as doctrines, beliefs and practices of a sacred past, found in particular religious communities [and] which is manifested in a set of strategies aimed at the preservation of that group's distinctive identity. (n.p.)

The world has already seen a number of incidences flowing from such an attitude of religious extremism, of which the 9/11 attacks (2001) in New York is emblematic. ${ }^{1}$ Driven by a basic set of beliefs, the perpetrators of these incidents inflict misery on large numbers of people who themselves are neither politically nor religiously involved. According to Grayling (2007), fundamentalists of various kinds:

$[M]$ urder those whom they see as infidels and apostates, and think of themselves as very good people therefore, because they see what they do as absolute obedience to the will of their deity. (pp. 110-111)

\section{The problem}

In principle, it should be possible to establish whether religious fundamentalism is indeed the default spirituality of the human being. We should somehow be able to ascertain whether we all are by nature, at our birth, preprogrammed to adhere to some or other form of fundamentalism, a default attitude that can only be changed by and through education and through life experience. However, we find ourselves confronted with at least two methodological obstacles in this regard.

\footnotetext{
The current strife in Syria, the recent 'Arab Spring' uprisings, the conflict between the Muslim north and the Christian south of Nigeria, and the attack on a shopping mall in Nairobi, Kenya, count as other examples. Peck (2006:173) correctly points out that differences can exist between atheists and theistic believers as well as within religious groups: 'We see dogmatism, and proceeding from dogmatism, we see wars and inquisitions and persecutions. We see hypocrisy: people professing the brotherhood of man killing their fellows in we see wars and inquisitions and persecutions. We see hypocrisy: people professing the brotherhood of man killing their fellows in
the name of faith, lining their pockets at the expense of others, and practicing all manner of brutality' (Peck 2006:184). In Wright's the name of faith, lining their pockets at the expense of others, and practicing all manner of brutality' (Peck 2006:184). In Wright's
(2009:421) view, 'the bulk of westerners and the bulk of Muslims are in a deeply non-zero-sum relationship, [and] by and large aren't very good at extending moral imagination to one another'. Alford (2009:57) concurs with him in saying that religious fundamentalism seems to be the cause of many of the world's ills, the reason for this being that people tend to operate from a narrow frame of reference (worldview) than what they are capable of, thereby failing to transcend the influence of their particular religion, culture, particular set of parents and childhood experience upon their understanding (Peck 2006:180). Alford (2009:57) sees 'religious fundamentalism as the cause of so many of the world's ills - suicide bombers [...], intolerance [...]' (cf. Potgieter, Van der Walt \& Wolhuter 2014:1 of 8).
} 
How can a researcher establish empirically the likelihood of religious fundamentalism being the default spirituality of the human being? There seems to be two avenues open to him or her. The first is to examine the spirituality of babies and very young children, to see whether religious fundamentalism is indeed their default spirituality. This is problematic as babies and small children cannot articulate their spirituality, and by the time they are able to do so, their spirituality already may have been affected by their education and life experience up to that point. If their spirituality indeed had been fundamentalist, it would have been affected by the pedagogical interventions of their parents and other influential persons in their society. They might already have learned about the dangers of religious fundamentalism and extremism, and about the value of tolerance and of a positive modus vivendi. This problem is compounded by the fact that the term 'spirituality' is notoriously difficult to define (Jones 2005:1-2). How could babies and young children then be expected to depict their own spirituality?

Another possibility is to go back in time to when people first became religiously aware. There are several problems in this regard as well. Firstly, if one looked at the progression of the human being from an evolutionist point of view, at what point in his or her evolution could one assume the human being to have developed some form of religious awareness? If for argument's sake, one could indeed establish the point at which the human being became religiously aware, how could one then establish whether that religious awareness was of a fundamentalist nature? That point in time is inaccessible to the modern researcher (Van der Walt \& Potgieter 2012:87-91). Or is it?

Certain converging arguments from evolutionary epistemology and palaeoanthropology bring to light that our earliest ancestors, the Cro-Magnon, were 'human beings' in every anatomical and behavioural way. Since its very beginnings, Homo sapiens possessed characteristics that made them uniquely different from their closest sister species, that is, characteristics such as consciousness, language, symbolic minds and behaviour, religious awareness and behaviour. Modern researchers are challenged to take seriously the fact that these human ancestors' ability to respond religiously to ultimate questions through worship and prayer is deeply embedded in the human species' symbolic, imaginative behaviour, and in the cognitively fluid minds that make such behaviour possible. Put differently, the Cro-Magnons of the Upper Palaeolithic seem to have had metaphysical systems or first religions, which almost certainly included notions about meaning, survival, beauty, life after death, and the 'other world' (Van Huyssteen 2004:217-218, 220). According to Van Huyssteen (2004), the emergence of:

[C]ognitive fluidity - the ability to entertain ideas that bring together elements from generally incongruous domains - most probably occurred at different times in different populations between 60000 and 30000 years ago. This involved an integration of technical intelligence, and led to the cultural explosion we now call the appearance of the human mind. It was this important step in the evolution of the human mind that ultimately enabled the human species to design complex tools, to create art, and to discover religious belief. (p. 221)

Now, assuming that Van Huyssteen and his evolutionary sources are correct in their reconstruction of the 'moment' when religious awareness emerged amongst anatomically and behaviourally modern human beings, that is, between 40000 and 30000 years ago, how do we know whether they practised a form of fundamentalist religion? We could presuppose that their religious awareness must have been of the most basic nature, a vague spiritual awareness of supernatural powers and 'gods' in nature, a similarly vague awareness of the presence of the ancestors and a tendency to ascribe life and power to inanimate objects (i.e. animism). Could we say, however, that their religion was fundamentalist, in the sense described earlier?

Seeing that the researcher cannot reach so far back in the history of mankind to answer this question, it is possible to consider another route: she could examine the holy books of the various mainstream religions to discover the nature of the religious awareness of the people figuring in those books. This may also be problematic because the religious sensibilities of the various actors in those books differ from holy book to holy book. Furthermore, as far as could be established, none of the extant holy books deliberately promotes a fundamentalist or extremist religious stance. In fact, most of the holy books associated with the mainstream religions propagate a balanced, loving, caring lifestyle and in principle condemn an attitude of hatred and intolerance. Only a biased reading of the holy books seems to result in those extremist views condemned by mainstream religious leaders.

\section{A note about method}

Because none of the empirical research routes seems to help us to find an answer to the conundrum stated in the title of this article, we had to put philosophy of religion to work. Philosophy helps bring clarity and understanding to questions that we all care about, in this case the question whether religious fundamentalism can and should be seen as the default spirituality of human beings (Dupré 2007:3). As Grayling (2007:7-8) mentions, Socrates said that the unconsidered life is not worth living. The 'considered life' is a life enriched by thinking about things that matter, including the human condition as reflected in his or her spiritual orientation, fundamentalist or otherwise. As teacher educators, greater understanding will help us know how to educate educators (teachers) to be able to contribute to the modus vivendi that we would prefer to take root in society. Education will become all the more daunting if we should be led to conclude that religious fundamentalism is indeed the default spirituality of the human being.

Because we could not find answers to the question in the title of this article through empirical investigative means, we opted for experiential interpretivism as underpinning methodology. Put differently, we tried to make sense of 
our observations and experiences with regard to religious behaviour amongst people. By observing and interpreting our observations and experiences, we searched for a plausible answer to the question whether religious fundamentalism was the default spirituality of the human being. A first step in getting a grip on the problem was to define the key concepts.

\section{Conceptual framework What is religion?}

The word 'religion' is derived from the Latin origin ' $r e$ ' [again] and 'ligare' [to be bound to]. It refers to the bond that a person feels with an 'arché', the basic force in his or her life, whether natural (self, material possessions, another person) or supernatural or transcendent (a god or other force). It is that point in a person's life or existence from which all of a person's life and worldview, his or her ultimate principles and values flow (Colson \& Pearson 2001:xiii).

According to the phenomenological and structural analyses of Van der Walt, Potgieter and Wolhuter (2010:29-52) and Van der Walt (2011:1-7) of religion, it is an organised collection of belief systems, cultural systems (i.e. narratives, symbols, traditions, sacred histories, etc.) and worldviews that relate humanity to spirituality, moral values and the origin and meaning of life. It includes the feelings, acts and experiences of people (individual or communal) so far as they apprehend themselves to stand in relation to whatever they may consider the divine.

\section{What are fundamentalism, radicalism and extremism?}

Fundamentalism, radicalism and extremism are closely related. Religious fundamentalism refers to a contextual condition where a group of people may decide to view their religion's role in public life to be greater than it realistically should be. Consequently, their behaviour is usually too religiously confident and/or they may engage in any sort of action out of religious conviction (Emerson \& Hartman 2006:128-129). Radicalism refers to the belief that there is a vital need for an awareness of the root causes and character of things, by which one can recognise and penetrate superficial or false appearances. In political or religious terms, this is often accompanied by the belief that society requires fundamental and drastic changes (Namakkal 2012:59-88). Extremism (at both ends of the religious and moral spectrum) is any ideology or act far outside the perceived religious or moral centre of a society, or one that otherwise violates common moral standards (Amjad \& Wood 2009:514-519).

\section{What is spirituality?}

The term 'spirituality' has at least two meanings, namely 'religious inclination' and a transcendental relationship with some 'beyondness'. Katz (2012:passim) relates 'religious inclination' to the four features of psychological maturity:

- well-being (i.e. personal growth, purpose in life, selfacceptance, autonomy and positive interpersonal relations)

- hardiness (i.e. resistance to stress, resistance to anxiety, resistance to depression, thriving under stress and surviving under unfavourable conditions)

- resilience (i.e. coping behaviour, coping in difficult situations, the ability to 'bounce back' and recoverability)

- coherence (i.e. comprehensibility, manageability and meaningfulness).

Regarding the second meaning, Jones (2005:1-9) suggests that 'beyondness' reflects four elements of spirituality, namely transcendence, connection, wholeness and compassion.

\section{What is a life and worldview?}

According to Olthuis (1989:2-3), a worldview (or vision of life) is a set of fundamental beliefs through which we view the world and our calling and future in it. The term 'life and worldview' refers to the deepest fundamental convictions of a person with respect to the Person or force that he or she regards as God or god, as the philosophers Taljaard (1976:13-14) ${ }^{2}$ and Scruton (2004:121) ${ }^{3}$ maintained. A worldview provides its adherents with a picture of reality about history, life and existence. It also reveals the way to salvation and healing (Olthuis 1989:2-3). Although a worldview is held by individuals, it is communal in scope and structure. It gives the terms of reference by which the world and our place in it are understood. Allegiance to a commonly held worldview promotes the integration of individuals into a group. Ironically, at times communality in terms of a particular worldview 'not only binds people together, but provides them with the tools and vocabulary to push with more sophistication their own internal differences' (Olthuis 1989:2-3).

Based on the insights flowing from these definitions, we reflected about the problem of religious fundamentalism as the human being's default spirituality. The following section contains the upshot of our experiential interpretative contemplation.

\section{The result of our reflection on the problem}

Our basic conclusion was that religion as defined and circumscribed seems to be indeed something fundamental to the nature and needs of human beings. This conclusion is based on the very fundamental nature of spirituality and a worldview.

We further concluded that the key to discovering whether the default spirituality amongst people amounts to religious fundamentalism lies in the relationship between religion (faith) and other human faculties such as reason and morality, as will be argued below.

2.Taljaard (1976:13-14) wrote: "But first of all we must remember that the three realities (God/god, creation and the laws governing creation) in their radical difference stand in a wonderful coherence to each other a coherence which we can never ignore or put aside when trying to get a correct view of reality'.

3.According to Scruton (2004:121), 'the search for the really real has tempted many phild phror-free error-free. But there is no point in aspiring to this perspective, unless one believes that there is something that resides there, and which has knowledge of the world as it really is. For it is only as a repository of knowledge (of the ultimate truth of the world) that this perspective can underpin our metaphysical convictions'. 
The human faculty known as reason ${ }^{4}$ (i.e. the ability to think and argue - the human mental life) seems to play a dual role in determining whether a person remains or becomes a religious fundamentalist or not, the first a more passive and potential role, and the second a more active and deliberate role.

\section{In terms of the first role, Law (2011) averred:}

Certainly, there can be a bad side to faith: a person who has given up on reason and who 'just believes' is easily controlled by his or her religious masters. Such people can easily be persuaded to do bad things, including killing those who don't agree with them. (p. 305)

This view is diametrically opposed to that of Dooyeweerd (1969) and others who correctly, in our view, insists that one can never 'give up on reason' because reason (together with other human attributes) forms part of the indispensable infrastructure of faith. The fundamental dependence of human self-knowledge on the knowledge of a god, God or ultimate source has its inner ground in the essence of religion as the central sphere of (the human being's) created nature' (Dooyeweerd 1969:I, 55) and can therefore never be relinquished or underutilised. After having considered the etymology of the word 'religion' as well as all the meanings that have been attached to the term through the ages, Van der Walt (2008:28) reaches a similar conclusion: 'In religion the emphasis is on man's bonding with or being bound to something or somebody; it indicates that man has to consider something, keep account of it'. On this view, all people are religious, therefore put their faith in some or other source or Source, whether immanent or transcendent. Their faith, irrespective of the nature or direction of that faith, is also always rooted in and built upon a human infrastructure that includes analytical activity, amongst others. Law $(2011: 343,354)$ inadvertently also supports this philosophical anthropology by stating that the human mind produces a 'rich inner mental life' consisting of understanding, thoughts, feelings and emotions.

Regarding the second role, the more active role of reason as part of the substratum of religion, religious thoughts and actions are based on deliberate reflection and reasoning. All people reflect about what they (should) believe in, what they should put their faith in. A religiously tolerant person, for instance, will allow others with opposing viewpoints to have their say and will then leave the upshot to what Grayling (2007:8-9) refers to as the democracy of ideas, that is, the power of argument to decide which ideas shall prevail. The only obligation should be honest reasoning. ${ }^{5}$ One can be confident,

4.As will be observed, we are extremely wary of assigning a dominant role and position to reason, that is, to lapse into some or other form of Rationalism. Postmodernism has convincingly discredited this view of reason. Our view of the role of reason in human life and existence can be described as postpostmodern or role of reason in human life and existence can be described as postpostmodern or post-post-foundationalist; we
with other human attributes.

5.La Folette (2007:7) gives two sets of practical guidelines for conducting such a reasonable discussion. Firstly, we have to ask ourselves whether an argument or a view is plausible, defensible, based on full information, careful calculation, astute perception, and if it has successfully survived the criticism of others in the marketplace of ideas (i.e. the power of argument). The second set entails the execution of six steps to decide whether a view, argument or action can be morally justified: (1) we should strive to make an informed decision based on the best evidence and then act should strive to make an informed decision based on the best evidence and then act accordingly, even though the best evidence will never guarantee certainty; (2) to make such an informed decision, the discussants should understand the relevant issues; (3) take a longer term perspective; (4) set aside irrational biases; (5) and inculcat a willingness to subject their tentative conclusions to the criticisms of others; (6) finally, the discussants should acknowledge their uncertainty, admit their fallibility, and be prepared to consider new ideas, especially when they are supported by strong arguments. (cf. Also Potgieter et al. 2014:1 of 8). he asserts, that 'in most cases the unbiased reasonings of an informed mind will come out in favour of what is good and true' (also see Morton 1998:171). Free and questioning discussion often leads to discovery of the truth, in casu the reasons for religiously fundamentalist beliefs and actions. Peck (2006:4) agrees: it is only when we encounter problems (in this case, with a fundamentalist life- and worldview) that we grow mentally and spiritually (cf. Potgieter et al. 2014:4 of 8). Van Huyssteen (2004:11) expounds this same idea in different terms. In his opinion, all the many faces of human rationality relate directly to the human being's pretheoretical reasonableness, a 'common sense' rationality that informs and is present in our everyday goal-directed actions. On the basis of this every day and ordinary means, people are able to make rational judgements and decisions. On the basis of this activity, they can distinguish values such as intelligibility, discernment, responsible judgement, and deliberation which guide them when on an intellectual level they have to make responsible choices and commitments. In Van Huyssteen's (2004) words:

It is in the pursuit of these goals and ideals that we become rational persons as we learn the skills of responsible judgement and discernment, and where we articulate the best available reasons we have for making what we believe to be the right choices, those reasons we have for holding on to certain beliefs, and the strong convictions we have for acting in certain ways. (p. 11)

Based on insights such as these about the active role of reason in our religious lives it can be concluded that no religious fanatic, fundamentalist or extremist can be seen as a blameless victim of influential religious leaders. To become a religious fanatic, extremist or fundamentalist requires pretheoretical (common sense) rational activity in the form of a conscious decision to practise a particular form of faith.

As intimated, the substratum of faith consists of more aspects than reason alone, however. Faith not only depends on reason but also on ethical, juridical, economical, aesthetical, social, historical (i.e. cultural and/or formative), psychological and physical considerations, norms and convictions. Reciprocally, faith directs and determines all of these human attributes or functions towards servitude to the perceived ultimate source or Source. It is just as impossible for a person to give up on reason as it would be to give up on, for instance, his or her psychological makeup or ethical or moral persuasion. On this philosophical anthropology, religious fanaticism, extremism and fundamentalism are based not only on reason, reasonable choice, but ethical choice, juridical, economical et cetera considerations as well.

Amongst these human functions or capabilities, ethics or morality seems to play a major role in preventing a person's religious commitment from deteriorating into fundamentalism and extremism. Collins (2007:27) correctly states that ethical considerations (i.e. love for the other, sometimes referred to as altruism) may lead humans to make sacrifices that lead to great personal suffering (note: not suffering to others as the result of an indiscriminate 
fundamentalist terrorist act, for instance), injury or death, without any evidence of benefit. In Collins's opinion, if we carefully examine the inner voice referred to as our conscience, we may find that the motivation to practise this kind of love exists within all of us, despite our frequent efforts to ignore it. Put differently, even a religious fanatic will feel love and compassion for certain individuals (his or her children, spouse and other family, for instance). What then might inspire such a person to ignore this inner ethical drive and perpetrate acts of violence on others? Would it not be fair to conclude that for some or other reason, perhaps of a psychological nature, such a perpetrator might prefer to ignore the voice of reason mentioned earlier, and also the voice of conscience? Cultural-historical or social reasons might also come into play here. Or might this tendency to ignore be blamed on such a person's spirituality?

Spirituality, in the one sense mentioned above, refers to a deep, fundamental religious need of human beings. It refers to one of the deepest dimensions of religion as experienced by human beings. In our opinion, spirituality indeed refers to something quite fundamental in the lives and existence of human beings. Life and worldview likewise seems to be something deeply fundamental in the lives of human beings. The term 'life and worldview' refers to the deepest fundamental convictions of a person with respect to the Person or force that he or she regards as God or god, as mentioned. In saying this, we agree with John Calvin who claimed that all humans are born with the semen religionis [the seed of religion]: to be religious is a fundamental trait of the human being. Wright (2009:63) concurs by saying that human beings, owing to quirks of evolutionary history, 'are susceptible to religious ideas and feelings'. There can be no doubt then, based on the conceptual information available to us, that religious fundamentalism must be the default spirituality of the human being - but this is counteracted from the moment of birth, and particularly the first six or seven formative years of life, by the development of rational and ethical (and other) abilities or functions of the individual and also by his or her education.

None of the aforementioned functions or attributes of the human being, including faith, can be fully developed, unfolded or unlocked without exposure to education. The natural religious-fundamentalist inclination of the human being tends to be counterbalanced by the education socialisation - that he or she receives from the moment of birth and particularly, as mentioned, the important first six or seven formative years of life. In some cases, the education that children or young people receive might tend to indoctrinate them, or in other words, teach them to disregard the views, interests and needs of others and to inflict antisocial acts on others for political, social or totally selfish reasons and purposes. Our investigations show, however, that indoctrination is not the default mode of educating; most educators wish to contribute towards the formation of wellbalanced and responsible members of society, people who strive towards a healthy and positive modus vivendi. (There are exceptions to this rule, as will be argued below when a number of specific issues will be addressed.) Through education a child learns, for instance, that human society benefits by permitting a variety of lifestyles to coexist and flourish, because they represent experiments from which much might be learned about how to deal with the human condition (Grayling 2007:8). Through education, young people learn that there is plenty of room in the world for alternative views to coexist. Learning how to do so is one aim of the civilised life. This idea also surfaces in the thinking of De Botton (2012:115): to learn to tolerate - and hence not act in fundamentalist ways - requires a 'degree of urgent didacticism'. The purpose of education, it can be argued, is to prepare young people for a future life as part of a positive modus vivendi.

The term modus vivendi originated in liberal circles to express the belief that there are many forms of life in which humans can thrive. The aim of a positive modus vivendi is not to still the conflict of values associated with the different forms of life but rather to reconcile individuals with different value systems, and to redirect their even conflicting values towards a life in common that would be good for all (Gray 2009:25). Because there are so many possibilities worth exploring, we can neither expect nor desire that every person or every society should converge on a single way of life. Every individual has a right to his or her own way (Schneller 2011:189-190); his or her claim to certain values should therefore be respected (Parekh 2000:155). As De Botton (2012:83) remarked, we will never discover cast iron rules for a positive modus vivendi but this does not detract from the need to attempt to live together peacefully. The lack of agreement about what constitutes the good life for everyone, and the role that religion or religious differences could play (Wright 2009:43) should not in itself be enough to disqualify us from at least investigating and promoting the possibilities of a positive modus vivendi.

Education is the key to a positive modus vivendi; it makes civil society possible (Grayling 2002:157). Young people have to be guided to understand the possibilities of, and requirements for, living peacefully together in a diverse society. The aim of dialogue about modus vivendi is to try and lessen the tensions between the different religions, thereby promoting a peaceful and just society. Living peacefully with others and tolerating their religious and other idiosyncrasies should not be based on opportunism, personal profit or peace as such, but rather be an expression of interest in others and their values, of trying to know as much of them as possible in order to respect them (Van der Walt 2007:187, 213).

A number of questions flow from the above discussion about the role of education as a way of combating religious fundamentalism: ${ }^{6}$

- Does reason operate neutrally or may it be used in support of the dominant ideology or worldview? (In the aforementioned discussion, reason is employed in the service of 'tolerance' as a way of ensuring a positive modus vivendi.)

6. We are grateful to an anonymous referee for posing these questions as they cast more light on the problem 'religious extremism' within a pedagogical context. 
- What are the limitations of reason to act as the final arbiter in religious and ethical issues?

- Do people make religious (and other) decisions based on reason or do they use reason to support their religious (and other) decisions?

In our opinion, reason never operates neutrally as it is always guided and determined by some or other religious or spiritual and worldview commitment. In theory, therefore, it can be employed to support a certain ideology or worldview. By the same token, it can be used to promote a positive modus vivendi. As argued above, although reason serves as one of the main guides for human actions and behaviour, its role is constrained by several other human capabilities or functions, amongst which the most prominent would be the ethical function of love for the other, acting in the interest of the other, and compassion for the other. As also mentioned, psychological and cultural-historical and social considerations might inspire a particular individual or group to ignore the voices of reason and of conscience (morality). The fact that human beings possess the ability to reason logically is no guarantee that a certain individual or group might not act irrationally or unethically. The laws of reason and of love can be transgressed because they are norms and not natural laws (such as gravity):

- What keeps reason itself from becoming an extreme foundational norm by which to judge others and indoctrinate them to give up their points of view in order to uphold a reasonable lifestyle?

As intimated, the fact that human beings possess the faculty of reason does not guarantee a balanced lifestyle. It is conceivable that under certain circumstances, a person's ability to reason in a manner that would be to the advantage of all individuals, groups and to society in general, can be compromised. Psychological trauma (e.g. the loss of loved ones because of the actions of another person or group) might lead an individual to ignore the voices of both reason and love (compassion). Ideally, however, reason and love would be the guiding lights in contributing to a positive modus vivendi. In our opinion, to act contrary to these guidelines would point towards some or other form of pathology:

- Who determines what a reasonable lifestyle is? Can we trust those who claim to tell us what 'reasonable' behaviour is? On what grounds do they do so?

Based on our conclusion that to act contrary to what would be reasonable and ethical in promoting a healthy modus vivendi would point to some or other form of pathology, we have to assume that all those who listen to the voices of reason and love and act accordingly in a balanced way to the advantage of all concerned might help us to understand what is meant by a 'reasonable and ethically balanced lifestyle':

- Is it reasonable to tolerate opposing views if your logic has brought you to the conclusion that these views may harm the positive modus vivendi of the group or the world? Can people, in the name of reason, thus, persecute others for being 'unreasonable?' Can reason be employed coercively?

As mentioned in response to the previous question, only the voices of reason and love that are to the advantage of all should be seen and heard as guidelines towards the creation of a positive modus vivendi. Those voices that do not have this objective should be ignored or at best tolerated, on condition that they do not inspire actions that are not in the interests of all concerned. If, for instance, they lead to antisocial acts they have to be condemned and ways have to be sought to understand the pathology that inspired them:

- Should the question not be: 'What are the key fundamentals of the different religions?' rather than 'How should we try and keep people from radically living out those religious fundamentals?' If 'Love your enemies', and 'Do good to those who persecute you', belong to the fundamentals of, for example, the Christian religion, then the educative aim would surely be to make Christians act more radically and extremely in line with these fundamental propositions?

We agree with the basic argument contained in this question. Again, people should be expected to act according to the basic tenets of their religions, on condition that those tenets do not contravene the norm mentioned earlier, namely that they have to conform to the voices of reason and love and have the best interests of all concerned in mind. Because it is difficult for a single individual to know and understand all the basic precepts of all religions (even within a certain country), we have to adhere to the 'voices of reason and love aimed at promoting the interests of all concerned'. We have to question actions that do not conform to this norm:

- What is the difference between persuasive and coercive fundamentalism? (We remarked above: 'Regarding religious fundamentalism, radicalism and extremism, we found that only relatively small groups from virtually all religions fall in this category. They tend to promote their religious interests through violence and general antisocial behaviour'). Can Christians, for example, still be missionaries, propagating their faith as being the final truth for mankind and asking for radical conversions to it and the embracing of an extremely different lifestyle from society's current norms, without being coercive?

The norm formulated above is the key to the answer. A person can only persuade another on the basis of the norm. Coercion is required when another norm is applied, such as 'if you do not join my religion, I shall regard you as my mortal enemy'. Coercion therefore has to be condemned. The same applies for education in accordance with the norm; indoctrination violates the spirit of the norm:

- Is it reasonable to argue that teachers are not prone to indoctrinate others - against the general argument of the article that people are religious fundamentalists at heart? What about the religious schools in Pakistan or the secular schools in the West? (Again, we stated above: 
'Our investigations show, however, that indoctrination is not the default mode of educating; most educators wish to contribute towards the formation of well-balanced and responsible members of society, people who strive towards a healthy modus vivendi').

In our experience, most teachers tend to educate (i.e. to form), guide and enable the learners entrusted to them. However, we do not deny that there might be two categories of teachers or educators who might be tempted to indoctrinate the learners entrusted to them, namely (1) those who have not been adequately trained and therefore do not know the difference between education and indoctrination or coercion, and (2) those working in environments where, due to (national) religious commitment and social expectations, the upcoming generations are expected to be indoctrinated in a certain religion and into performing certain actions. To indoctrinate is to prevent the learner from having more than one option to choose from. This is not education in the true sense of the word. The norm formulated earlier comes into play here as well; is what teachers such as these are doing based on the voices of reason and love and is it to the advantage of all concerned? Only the teachers involved in a certain context can provide an adequate answer to this question:

- Can we entrust a teacher who is not of the same fundamental persuasion as the learners to guide them to make reasonable decisions regarding their religion?

- What fundamental presuppositions drive the teacher's view of 'reasonable'?

- If the teacher does not believe that miracles are reasonable, should he guide his students to reject them?

- Can he challenge them in a way that allows his own views to be challenged, or will he end up being a propagandist for his fundamental worldview?

These are four of the perennial questions associated with secular public schooling. Our answer is that teachers and learners should ideally belong to the same religion, particularly in the first six or seven years of schooling whilst the learners are still being steeped (not indoctrinated) in the tenets of their own religion. This will prevent confusion in their young minds about the various religions. The teacher must refrain from indoctrination or coercion, even if learners belong to the same religious group as all the learners in the classroom. Indoctrination robs learners of (religious) choice. Religion education should therefore be offered in a balanced or pedagogical manner, that is, for the purpose of leading, guiding, enabling and equipping the learners to come to personal choices and actions.

A teacher from a different religious persuasion might indeed be tempted to act contrapedagogically, that is, to indoctrinate or coerce:

- Such an individual might try to confront learners with religious precepts that are foreign to them.

- He or she might try to indoctrinate learners with foreign notions.

- He or she might challenge them strongly to defend certain of the key tenets of their religion (which learners might not be able to do yet).

- He or she might act in propagandist ways.

In summary, the teacher and learners ideally should be of the same or similar religious persuasion. If, as in a secular school, this is not possible, the teacher has to be cognisant of all the pitfalls and should be aware of the norm, as stated, of reason and love to the advantage of all concerned.

\section{Implications for teacher education}

The aforementioned religio-philosophical-anthropologicalpedagogical view highlights at least ten important facets of teacher education, irrespective of where it occurs:

- Prospective teachers should be reminded that religion or spirituality is something fundamental to their own lives as well as those of their learners. This religious or spiritual awareness should be harnessed in a pedagogical context to give meaning to the personal existence of all concerned. They should, in particular act reasonably (i.e. based on healthy common sense), with love, caring and compassion for the sake of promoting the interests of all concerned.

- Student teachers should also understand the anatomy of the phenomena that we refer to as religion and/or spirituality. In particular, they should understand both the passive and active roles that reason can and should play in how religion or spirituality is expressed and lived by sane and balanced individuals.

- Student teachers should come to understand their own rich inner lives as well as those of their learners. Whilst people are in essence religious or spiritual beings, they are more than that; they are also ethical, economical, aesthetical, juridical, thinking (i.e. reasoning), psychological and physical beings (to name only a few of their modalities). Teacher education and education in general should be aimed at unfolding all of these modalities in order to ensure that pedagogically balanced people are sent into life as teachers or as school finishers.

- Student teachers as well as their learners should be taught the power of argument and the intricacies of reasoning. They should be encouraged to apply their critical powers also to the religious stance that they have been inculcated with by their parents and other educators. They should be equipped to enter into free, reasonable and open discussion with others who have a different religious or spiritual commitment. They should avoid as far as possible the use of what Richard Rorty (2003:147) referred to as conversation stoppers, so-called 'end vocabulary'. ${ }^{7}$

- Both student teachers and their future learners should be encouraged to examine the religion that was handed down to them by their educators in a critical manner, and they should be given the opportunity to decide on

7.Typical examples of 'end vocabulary' include statements such as: 'My religious convictions are non-negotiable. I really don't care to discuss them with you or with anyone else'; 'I believe only what my religious convictions tell me to believe. I am not interested in whatever your religion might entail and encourage you to do what you think is right'. 
their own religious or spiritual commitment. This critical process should be based on rational decision, and not on emotion alone.

- Student teachers and their future learners should be made aware of the persuasive abilities of demagogues and other influential people who are themselves driven by forms of religious fanaticism, extremism and fundamentalism. Such influential people appear in all religions and should be avoided or critically disempowered by rational argument and on the basis of the norm formulated in the first bulleted paragraph. Avoidance of such influences will be to the advantage of a healthy modus vivendi and religious tolerance.

- Student teachers should be informed about the power of education, and hence the importance of avoiding indoctrination in any form, however well intended. One way of doing this is by dialogically engaging with students by allowing influences to flow reciprocally between educator and student, thereby allowing learning to occur on both sides of the dialogical divide.

- Both student teachers and their future learners should be encouraged never to give up on reason which is one of the modalities of the human being, amidst several others. Put differently, prospective teachers should also be exposed to the subjects of Logics and Philosophical Epistemology. They have to understand how reason(ing) works, and how one could employ logic to persuade another to be critical about the self and his or her personal religious or spiritual convictions. This is one of the societal and personal objectives of education; personal goals generally include producing a rational person capable of independent and critical thinking. As always, rationality has to be counterbalanced by love, caring and compassion, and also by the other modalities of being human.

- Student teachers and their learners should be made aware of the current tendency to replace all forms of mainstream religion and religious commitment in general with some or other form of spirituality. Space does not allow a detailed discussion of spirituality here; suffice it to say that the curriculum for teacher education should also contain a chapter on spirituality and how it determines human behaviour, also in relation to religious or spiritual fundamentalism.

- Student teachers should be educated to understand that to become a balanced, integrated person, not inclined to religious fundamentalism, extremism and fanaticism depends on the forming, guiding, equipping and stewarding functions of education. They should understand that the key feature distinguishing human beings from other animals is that the human being can be educated. The human being is an open possibility due to the fact that it can be educated (Schmidt 1973:1).

\section{Conclusion}

As Kelchtermans (2012:2) correctly concluded, the profession of the teacher does not consist of the mere application of a set of learned techniques. The teacher's professionalism comes to the surface in his or her practice, his or her everyday educative interaction with the learners entrusted to him or her. This is where the ten pointers outlined come into play. Whilst the teacher can never be sure about the effects of his or her educative interventions, and despite the demands of performativity and efficiency in education (Kelchtermans 2012:5-8, 12), future teachers should be equipped to use the substantial autonomy and space in their interaction with their students for the purpose of not only guiding the latter away from all forms of religious fundamentalism but to educate them to become religiously or spiritually balanced individuals, worthy members of their communities. This forms part of their spiritual and moral obligation towards their students.

\section{Acknowledgements Competing interests}

The authors declare that they have no financial or personal relationship(s) that may have inappropriately influenced them in writing this article.

\section{Authors' contributions}

F.J.P. (North-West University) was responsible for initiating and conceptualising the research. J.L.v.d.W. (NorthWest University) was responsible for the methodological and epistemological scaffolding of the article. The tasks surrounding literature scooping, as well as the drafting of various preliminary versions of the article, were more or less equally shared between F.J.P. and J.L.v.d.W.

\section{References}

Alford, H., 2009, How to live: A search for wisdom from old people, Twelve Books, New York.

Amjad, N. \& Wood, A.M., 2009, 'Identifying and changing the normative beliefs about aggression which lead young Muslim adults to join extremist anti-Semitic groups in Pakistan', Aggressive Behavior 35(6), 514-519. http://dx.doi.org/10.1002/ in Pakistan, 20325

Collins, F., 2007, The language of God: A scientist presents evidence for belief, Pocket Books, London.

Colson, C. \& Pearson, N., 2001, The Christian in today's culture, Tyndale House Publishers, Wheaton.

De Botton, A., 2012, Religion for atheists, Hamish Hamilton, London.

Dooyeweerd, Dh T., 1969, A new critique of theoretical thought, The Presbyterian and Reformed Publishing Company, Phillipsburg.

Dupré, B., 2007, 50 Philosophy ideas you really need to know, Quercus, London.

Emerson, M.O. \& Hartman, D., 2006, 'The rise of religious fundamentalism', Annual Review of Sociology 32, 127-144. http://dx.doi.org/10.1146/annurev. soc.32.061604.123141

Gray, J., 2009, Gray's anatomy, Allen Lane, London.

Grayling, A.C., 2002, The meaning of things, Phoenix, London.

Grayling, A.C., 2007, The meaning of philosophy: Applying philosophy to life, Phoenix, London.

Jones, L., 2005, 'What does spirituality in education mean? Stumbling toward wholeness', Journal of College \& Character 6(1), 1-7.

Katz, Y., 2012, 'The definition of spirituality in faith- and knowledge-based religious education', paper presented at 18th conference of the International Seminar on Religion, Education and Values (ISREV), Finland, Turku, 29 July - 03 August.

Kelchtermans, G., 2012, De leraar als (on)eigentidjse professional: Reflecties over de 'modern professionaliteit' van leerkrachten, Centrum voor Onderwijsbeleid, -vernieuwing en leeraaropleiding, Katholieke Universiteit Leuven, Leuven.

La Follette, H., 2007, Ethics in practice, Blackwell Publishing, Malden.

Law, S., 2011, The complete philosophy files, Orion House, London.

Morton, A., 1998, Philosophy in practice, Blackwell Publishers, Malden.

Namakkal, J., 2012, 'European dreams, Tamil Land: Auroville and the paradox of a postcolonial utopia', Journal for the Study of Radicalism 6(1), 59-88. http://dx.doi. org/10.1353/jsr.2012.0006 
Olthuis, J.H., 1989, 'On worldviews', Christian Scholar's Review 14(2), 1-12.

Parekh, B., 2000, 'Non-ethnocentric universalism', in T. Dunne \& N.J. Wheele (eds.), Human rights in global politics, pp. 128-159, Cambridge University Press, Cambridge.

Peck, M.S., 2006, The road less travelled, Random House, London.

Potgieter, F.J., Van der Walt, J.L. \& Wolhuter, C.C., 2014, 'Towards understanding (religious) (in)tolerance in education', HTS Teologiese Studies/Theological Studies 70(3), Art. \# 1977, 8 pages. http://dx.doi.org/10.4102/hts.v70i3.1977

Rorty, R., 2003, 'Religion in the public square', Journal of Religious Ethics 31(1), 141149. http://dx.doi.org/10.1111/1467-9795.00127

Schmidt, W.H.O., 1973, Child development: Human, cultural and educational context, Harper and Row, New York.

Schneller, P.L., 2011, 'The creative spirit', in P.L. Schneller \& C.C. Wolhuter (eds.), Navigating the C's: An introduction to comparative education, pp. 169-192, Keurkopié, Potchefstroom.

Scruton, R., 2004, Modern philosophy: An introduction and survey, Random House/ Pimlico, London.

Taljaard, J.A.L., 1976, Polished lenses, Pro Rege, Potchefstroom.

Van der Walt, B.J., 2007, Transforming power: Challenging contemporary secular society, Institute for Contemporary Christianity in Africa, Potchefstroom. http:// dx.doi.org/10.1080/09637490903500507
Van der Walt, B.J., 2008, Man and God, Institute for Contemporary Christianity in Africa, Potchefstroom.

Van der Walt, J.L., Potgieter, F.J. \& Wolhuter, C.C., 2010, 'The road to religious tolerance in education in South Africa (and elsewhere): A possible "martian perspective", Religion, State and Society 38(1), 29-52.

Van der Walt, J.L., 2011, 'Understanding the anatomy of religion as basis for religion in education', HTS Teologiese Studies/Theological Studies 67(3), Art. \# 924, 7 pages. http://dx.doi.org/10.4102/hts.v67i3.924

Van der Walt, J.L. \& Potgieter, F.J., 2012, 'The origins of religion as historical conundrum: Pedagogical and research methodological implications and challenges', in N. Popov, C. Wolhuter, B. Leutwyler, G. Hilton, J. Ongunleye \& P. Almeida (eds.), International perspectives on education: 10th annual conference of the Bulgarian Comparative Education Society, BCES conference proceedings, Sofia, Bulgaria, 12-15 June, pp. 87-91.

Van Huyssteen, J.W., 2004, Alone in the world? Human uniqueness in science and technology, William B. Eerdmans Publishing Company, Grand Rapids.

Wolmarans, H., 2013, 'Some comments on Christian-Fundamentalist values: The impact of religious values on present-day realities', paper presented at the Research Institute for Theology and Religion's Forum for Religious Dialogue (FRD) University of Pretoria, Pretoria, 07 March.

Wright, R., 2009, The evolution of God, Little, Brown and Company, New York. 